\title{
O talismã de Furio Jesi
}

Giorgio Agamben*

Quando Furio Jesi, em 1972, confia às páginas de Comunità a "Leitura do 'Bateau ivre", encontra-se em um ponto decisivo do seu itinerário espiritual. Com a publicação de Germania segreta (1967) e de Letteratura e mito (1968), o enfant prodige, que aos quinze anos havia atravessado os impenetráveis caminhos da egiptologia, já tinha se imposto como o mais inteligente estudioso italiano de mitologia e ciência das religiôes e, ao mesmo tempo, como uma das personalidades mais originais da cultura daqueles anos e difícil de rubricar nos limites de uma disciplina acadêmica. Se Letteratura e mito é sem dúvidas um dos livros que contam no magro balanço da ensaística italiana do século $\mathrm{XX}$, é porque o autor consegue a todo instante quebrar as categorias sobre cuja oposição fundavam-se as frágeis certezas da ideologia italiana do pós-guerra: racionalismo/irracionalismo, mito/história, laicismo/religiosidade, esquerda/direita. Com um gesto simétrico ao de Apuleio (evocado justamente no fim do livro) que, escrevendo seu romance, de modo contínuo exorciza e profana sua própria conivência com o mundo mágico, Jesi instala seu trabalho na terra de ninguém em que essas oposiçôes se indeterminam e revelam, por fim, sua secreta solidariedade (cuja saída desastrosa temos hoje diante dos olhos).

A "Leitura" é, nessa perspectiva, um documento único das dificuldades e dos riscos, mas também da riqueza e das aberturas, implícitas nessa situação extrema. De um lado, ela desenha uma cartografia sumária do território inominado entre a história e o mito a cuja exploração serão dedicadas as obras que Jesi conseguirá levar a termo nos oito anos que o separam da morte; de outro, ela funciona como uma espécie de talismã no qual o autor, antes de continuar sua viagem, compendia os próprios "pensamentos secretos" e restabelece, no passeio vertiginoso de poucas páginas, os paradoxos e as aporias de sua pessoal experiência de mitólogo, projetando-a sobre a de Rimbaud. Não surpreende, portanto, que, na "Leitura", um lugar central seja
*Fonte: AGAMBEN, Giorgio."Il talismano di Furio Jesi”. In: JESI, Furio. La Lettura del "Bateau Ivre" di Rimband. Macerata: Quodlibet, 1996. p. 5-8. Tradução de Vinícius Nicastro Honesko. 
1. Agamben chama a atenção para o jogo linguístico elaborado por Jesi para elaborar um dos pontos fundamentais de seu conceito de "máquina mitológica". Cf. a nota 15 do ensaio "Leitura do 'Bateau ivre'", na página 74 deste número". (N.T.)

2. Agamben não dá indicação, mas se trata de uma citação não da "Leitura", mas do ensaio $A$ Festa e a máquina mitológica cuja tradução ao português foi recentemente publicada no Boletim de Pesquisa Nelic. Cf.: JESI, Furio. A festa e a máquina mitológica. Tradução de Vinícius N. Honesko. In: Boletim de Pesquisa Nelic, UFSC, Florianópolis, v. 14. n. 22, p. 53, 2014. (N.T.) confiado a uma aporia propriamente política. Não apenas, com efeito, a evocação de Rimbaud lhe permite escrever uma página na qual vibra uma inconfundível marca de memória pessoal e que está entre as coisas mais belas já escritas sobre a relação entre cidade e política ("Pode-se amar uma cidade, podem-se reconhecer suas casas e suas ruas nas próprias memórias mais remotas e secretas; mas só na hora da revolta a cidade é sentida verdadeiramente como o 'haut-lieu' e ao mesmo tempo como a própria cidade... A gente se apropria de uma cidade fugindo ou avançando no alternar-se dos ataques muito mais do que brincando quando criança em seus pátios, ou por suas ruas, ou passeando mais tarde com uma mulher..."); mas todo o texto corre sobre a oposição irresoluta entre a revolta, que é sempre experiência de uma suspensão do tempo histórico, e a revolução, definida, ao contrário, como o complexo das açóes destinadas a mudar no tempo histórico uma determinada situação. À oposição revolta/revolução corresponde aquela entre "este mundo" e "outro mundo", produzida pela "máquina mitológica" que Jesi vê em funcionamento na poesia de Rimbaud.

Se não estamos enganados, a "Leitura” é um dos primeiros textos em que Jesi apresenta esse conceito, o qual nomeia o fruto mais próprio de seu trabalho de mitólogo, que será de todo articulado no ensaio de 1973, A Festa e a máquina mitológica. Segundo Jesi, não há uma substância do mito, mas somente uma máquina que produz mitologias e que gera a tenaz ilusão de selar o mito dentro das suas próprias e imperscrutáveis paredes. Entretanto, seria inútil opor à máquina a inexistência do mito: a antítese élnão é é impotente tanto para atingir quanto para apenas criticar eventos que se colocam por definição em um outro mundo (e dos quais, portanto, só se pode dizer, nos termos de Jesi, que não existem aqui [ci non-sono] ${ }^{1}$ : "não há fé mais exata num 'outro mundo' que náo existe aqui [ci non-è] do que a declaração que tal 'outro mundo' não existe"). A potência insuperável da máquina está, com efeito, na tensão que ela produz entre mito e mitologia, entre o preexistente e o existente: "a máquina mitológica é auto-fundante: coloca sua origem no fora de si que é o seu interno mais remoto, seu coração de pré-ser, no instante em que se coloca em ato"2.

A inevitabilidade da máquina, que condena ao naufrágio tanto a revolta quanto a revolução (ambas exemplificadas em Rimbaud), é confirmada com força por Jesi em um ponto crucial da sua leitura: "Ambas, de resto, a revolta e a revolução não contradizem em nível conceitual o modelo proposto pela máquina mitológica. Pelo contrário: na perspectiva aberta, seja por uma, seja por outra, esse modelo acaba por se identificar com o a priori que permanece como fundamento sólido e obscuro do processo gnosiológico. Frente à essência do lugar comum - ou à essência do mito - não há autêntica alternativa conceitual, mas 
apenas alternativa gestual, de comportamento, só que de comportamento que permanece circunscrito dentro da caixa delimitada pelas paredes da máquina mitológica. Revolta e revolução, em nível conceitual, permanecem apenas diferentes articulaçôes (suspensão do tempo; tempo "certo") do tempo que vige no interior daquela caixa."

Ainda que Jesi nunca o diga de maneira explícita, é lícito supor que esse "fundamento sólido e obscuro" do processo gnosiológico não seja, em última análise, nada mais que a linguagem. Toda língua (seria possível dizer parafraseando uma tese de Humboldt que Jesi amava citar) lança ao redor do povo que a fala uma espécie de círculo mágico do qual não é possível sair a não ser com a condiçáo de entrar no círculo de uma outra língua e de um outro povo. O mito é esse círculo mágico, e a esfera das coisas que não existem aqui [ci non-sono] com a qual ele se identifica é o que a linguagem humana incessantemente produz e pressupóe no seu coração de não-ser.

É possível sair do círculo, "quebrar a raiz do tempo" que se esconde entre as paredes impenetráveis da máquina (que, segundo Jesi, assinalam, como aquelas da linguagem, "a marca de confim do ser")? É no fim da "Leitura" que Jesi parece acenar para uma possibilidade desse gênero escrevendo: "Quebrar essa raiz significaria dispor de uma linguagem ou de um complexo de gestos capazes de afrontar a máquina mitológica num plano que consentisse declarar ao mesmo tempo a existência e a não-existência daquilo que a máquina diz conter...". Dois anos depois, no ensaio sobre Kerényi, ele cita a frase com a qual o grande mitólogo compendiava o comportamento justo em relação ao "mito da morte" na consciência de que "a morte é algo e ao mesmo tempo nada".

Nesse sentido, a "Leitura", na biografia intelectual de Jesi, representa por certo um daqueles momentos privilegiados em que é dado a um autor contemplar lucidamente, por um átimo, numa espécie de desencantada adivinhação, o próprio limite último e esbarrar, por assim dizer, na raiz mais íntima da sua experiência da linguagem. Junto a esse limite, no qual o coração da máquina coincide com a sua própria existência, o mitólogo deve depor seus instrumentos. A existência e a não-existência da máquina circunscrevem agora sua própria estratégia vital, decidem-se nas fronteiras da sua própria linguagem. 
